\title{
Ideological Guidance Based on the Characteristics of Students in Higher Vocational Colleges in the New Era
}

\author{
Tiantian Zhou \\ Shandong Vocational Animal Science and Veterinary College, Weifang, Shandong, China
}

\begin{abstract}
To do a good job in ideological guidance of higher vocational students in the new era, we should first understand the position of the times and the characteristics of students; and then accurately grasp the essence of student ideological guidance; finally, use some pioneer and innovative leading concepts to improve the true ability of educating students.
\end{abstract}

Key words: vocational students; thought lead; new era

\section{Introduction}

Higher vocational students are one of the most important sources of national talent development, and their moral qualities, spiritual qualities and values are of great significance to social development. In the new era, in view of the characteristics of students in higher vocational colleges, improving our educational ability is particularly important for leading students' thinking.

\section{Accurately Grasp the Development Direction of the Times Guided by the Ideological} \section{Guidance of Vocational Students}

The new era gives young students a new mission of thinking and leading. China has gradually entered the center of the world from an ancient big country. In the new historical position, the country needs unswerving, enterprising and unremitting people, instead of hesitating, slack, and faint-heart people. So young people should be aware of the general development trend of the new era, grasp the direction, be firm and confident, realize new challenges and make their own contributions.

The new era gives young students ideas to lead new tasks. In the new era, we need to train new people who can undertake the task of national rejuvenation. They have ideals, skills and sense of responsibility. They master high-tech development and can improve the country's core competitiveness. That is to say, the country's heavy equipment needs these new people as pillars.

The new group has given vocational young students new ideological guidance characteristics. From the perspective of age composition, most of them were born after 1998 or even after 2000; from the perspective of family structure, there are more sole offspring, more divorced families, and most of them are from single-parent families compared with undergraduates; from the perspective of material conditions, they have a relatively affluent life; from the perspective of environmental development, economic growth adjustment, ideological external factors and many career opportunities are

Copyright (C) 2020 by author(s) and Frontier Scientific Research Publishing Inc.

This work is licensed under the Creative Commons Attribution International License (CC BY 4.0).

$\mathrm{http}: / /$ creativecommons.org/licenses/by/4.0/ 
influencing them; from the perspective of lifestyle, all life is connected to the internet, and they can't do anything without the internet; from the perspective of psychological state, they are showing both dependence and self-reliance, unfettered but competitive, hedonic but also a spirit of struggle.

In summary, we should stick to the actual characteristics of the higher vocational student group in the new era and provide ideological guidance.

\section{Grasp the Spiritual Essence of the Ideological Guidance for Higher Vocational Students}

(1) Directional navigation is the main embodiment of the ideological guidance of higher vocational students. Ideological guidance is the prerequisite, and political firmness comes from ideological sobriety. In the political direction, we should adhere to the path of socialism with Chinese characteristics, and refrain from the old road of isolation and rigidity, and the evil road of changing the flag. We must make it clear that the pace of reform will not stop and the open process will not stop. In terms of value orientation, it guides students to combine self-value with social value. The course of life is to grasp the direction and path of life scientifically, and to create a valuable life in practice, so as to be internalized in the heart, externalized in the behavior, assimilated in the group and impacted in the environment.

(2) Cultivate people with good morals is the fundamental task of ideological guidance for higher vocational students. The answer to the question of "for whom, who to train, and how to train" is obviously. To aspire to the Chinese nation's great cause, it is necessary to cultivate generations who support the leadership of the Communist Party of China and our country's socialist system, and cultivate useful talents who are fighting for the cause of socialism with Chinese characteristics.

(3) The difference between right and wrong is the focus of the evaluation of ideological leadership of vocational students. In the face of major events, they have the ability to distinguish and compare; in the face of exchanges and confrontations, they have the ability to criticize and correct mistakes; in the face of multiculturalism, they have the ability to choose and identify; in the face of big winds and waves, they have the ability to persist and can withstand tests.

(4) The thought is effective or not is not a theoretical issue, but a practical issue. Practice is the fundamental criterion for testing the effectiveness of higher vocational students' ideological guidance in the new era. We should focus on seeing whether our students have progressed ideologically and politically, whether they can become talents, and make contributions to careers.

\section{Improve the Ability and Effective Way of Ideological Guidance for Higher Vocational}

\section{Students}

(1) Phenomenon and essence are mutually confirmed. We should not only grasp the essence of the spirit, but also enrich the form of expression. Besides, we should create the soul and educate them with culture, and do a good job of ideological guidance and promotion of human culture, campus culture and social culture, consumer culture and creative culture. Finally, we should guide students to talk about big topics from small events.

(2) Sensibility and rationality are fused. We should be good at shaking students with emotions and persuading them with reason. When teaching students, we should integrate feelings into reason, or put reason into context to express. Only by telling stories, reasoning, and extending the emotions behind, can we truly impress students and shock their hearts.

(3) Strengthen collaboration. We should guide students to establish the "Four Understandings", correctly understand the development trend of world and China, correctly understand Chinese characteristics and international comparisons, correctly understand the responsibilities of the times and historical missions, and correctly understand the relationship between lofty ambitions and down-to-earth.

(4) Lead the group with the Party. Use Party building to lead team building, use team building to lead clubs, and use 
Party power to unite students. The ideological and political education of higher vocational students is centered on Party building, the Party building of higher vocational students is centered on ideological construction, and the ideological construction of college students is centered on the education of ideology, belief and purpose. The Party member is a banner. We should improve the quality of Party members, give play to the vanguard and exemplary role of student Party members, organize and guide the majority of students to unite the Party style, and unswervingly follow the Party!

(5) Exchange roles between students and teachers in the process of education. Teachers should pay attention to maintaining equal identities with students and actively engage in classroom interaction. Students should take the initiative to think and integrate into the classroom to realize the construction of their own ideas and knowledge.

(6) Unify knowledge and action. We know that theory comes from reality, and theory guides practice. But how to transform the knowledge learned by students into practice? Teachers should set a good example and teach students to practice with their own actions.

(7) Make education pleasurable. Student activities should be suitable for the characteristics of young people in higher vocational schools: higher vocational students are in the puberty stage, and their physical and psychological are in the developmental stage, so they always appear energetic and active interest in many things, and sometimes they may even emotionally excited. In fact, their learning is very intense and competitive, so it is necessary to carry out more cultural and sports communication activities suitable for them, and integrate education into entertainment to attract, unite, and guide them.

\section{Conclusions}

Ideological and political guidance solves the problems of real learning, real understanding, real belief, and real use of vocational students. Effective guidance is the mission of motivating more vocational students to believe in Marxism and turning them into firm believers and loyal practitioners with the lofty ideals of communism and the common ideal of socialism with Chinese characteristics.

\section{Conflicts of Interest}

The author declares no conflicts of interest regarding the publication of this paper.

\section{References}

[1] Shi C.Z. (2020). On the Ideological and Political Work in Higher Vocational Colleges. Party History, (05): 58-59.

[2] Yu L.L. (2020). Thoughts on Ideological and Political Education Leading the Professional Quality Education of Preschool Students in Higher Vocational Education. Education and Teaching Forum, (26): 72-73.

[3] Zhao F. and Zou Z. (2017). Some Thoughts on Innovative Ideological Education Model Based on the Characteristics of Higher Vocational Students. Ideological Education Research, (06): 115-117.

[4] Hu Y.M. and Ou Y.L. (2020). Discussion on Ideological and Political Education in Student Management in Higher Vocational Colleges. Education and Teaching Forum, (26): 115-116. 